\title{
Market-based conservation: Aligning static theory with dynamic systems
}

\author{
Richard T. Woodward, Amanda Stronza, Elizabeth Shapiro-Garza and \\ Lee A. Fitzgerald
}

\begin{abstract}
This paper provides a broad evaluation of the implications of market-based conservation (MBC) strategies from economic, social and ecological perspectives. After reviewing the economic theory that underlies MBC initiatives, we develop a list of approaches that have been labeled as "market-based", and categorize them according to the degree to which they are free-standing markets or require the intervention of the state. A multidisciplinary critique reveals the potential problems and pitfalls of MBC are due to a lack of ability to deal with dynamic systems in the real world. The dynamics of these three systems can undermine the intended goals of $M B C$.
\end{abstract}

Keywords: Market-based conservation; incentive-based conservation; conservation policy.

\section{Introduction}

Over the last two decades, a broad variety of market-based conservation (MBC) approaches have been actively promoted in both the developed and developing world. Capand-trade systems for greenhouse gas emissions have been established for the European Union and elsewhere. Ecocertification labels can be found on everything from the lumber at Home Depot to coffee at Starbucks. Payments

Authors are listed in reverse alphabetical order. Senior authorship is shared.

Richard T. Woodward is at the Applied Biodiversity Science NSF-IGERT Doctoral Program, Room 210 Nagle Hall, Texas A\&M University, College Station, TX 77843-2258; and Department of Agricultural Economics, Texas A\&M University, College Station, TX 77843-2124. Email: r-woodward@tamu.edu

Amanda Stronza is at the Applied Biodiversity Science NSF-IGERT Doctoral Program, Room 210 Nagle Hall, Texas A\&M University, College Station, TX 77843-2258; and Departments of Recreation, Park, and Tourism Sciences and Anthropology, Texas A\&M University, College Station, TX 77843. Email: astronza@tamu.edu

Elizabeth Shapiro is at the Applied Biodiversity Science NSF-IGERT Doctoral Program, Room 210 Nagle Hall, Texas A\&M University, College Station, TX 77843-2258; and Departments Nicholas School of the Environment, Duke University, Durham, NC, 27705. Email: elizabeth.shapiro@duke.edu

Lee A. Fitzgerald is at the Applied Biodiversity Science NSF-IGERT Doctoral Program, Room 210 Nagle Hall, Texas A\&M University, College Station, TX 77843-2258; and Department of Wildlife and Fisheries Sciences, Texas A\&M University, College Station, TX 77843-2258. Email: 1fitzgerald@tamu.edu for ecosystem services (PES) programmes, which pay landowners for things like avoided deforestation or to reduce non-point source pollution, are increasingly prevalent. Ecotourism is marketed for a variety of destinations, from remote indigenous communities to gateway cities outside of national parks. These and other MBC approaches seem to have broad appeal to conservationists. In 2009, forty-three environmental scholars identified "one hundred questions of importance to the conservation of global biological diversity" (Sutherland et al., 2009: 559). Twelve of these included the terms ecosystem services, market, and economy, including: "How can biodiversity considerations be integrated into economic policies to reflect the monetary and nonmonetary value of biodiversity, ecosystem processes, goods, and services?" (Sutherland et al., 2009: 561).

Advocates of $\mathrm{MBC}$ have pointed to several advantages over conventional approaches to conservation. Economists note lower costs compared to state-led, "command-andcontrol" methods (Engel et al., 2008). Conservation organizations look to MBC for increased funding (Cleary, 2006). Others argue that MBC can be more effective at establishing "buy-in" from the owners or managers of working landscapes where conservation needs are greatest (Palmer et al., 2004; Spiteri and Nepal, 2006).

A wide variety of programmes have been labeled as $\mathrm{MBC}$, creating some confusion about what is and what is not a market based instrument. While economists' definition of a market can be quite broad (Roth, 2008; 
Pirard, 2012), many conservation programmes that are referred to as market-based do not involve any markets at all. Nonetheless, the term has become widely used and accepted for a wide range of conservation approaches.

Market-based conservation principles have also been critiqued. McCauley (2006), for example, posited that focusing solely on the economic benefits of conservation will weaken and dilute environmentalists' long-standing appeals for conservation on moral, altruistic, or aesthetic grounds. Others claim the focus on win-win, market-based solutions is overly simplistic and ignores instabilities or inequalities inherent in many markets (Chan et al., 2007; Büscher, 2008; Erhenfeld, 2008; Muradian et al., 2013).

We have two main goals in this paper. First, we seek to provide an overview of the economic explanation of why conservation measures are needed, paired with an organizing framework for the wide range of approaches that have been described as "market based". The range of MBC policies is vast, and our taxonomy helps classify them according to commonalities and differences. Later, we focus on three main ways policymakers from governments or NGOs can intervene to change the incentives to encourage conservation.

Our second goal is to provide a multidisciplinary critique of some potential problems and pitfalls of MBC. We do not argue that $\mathrm{MBC}$ is a failure; such programmes have created incentives to manage wildlife (Robinson \& Redford 1991), compensated landowners for habitat conservation (Rissman et al., 2007), and generated revenues to support stewardship of entire landscapes (Landell-Mills \& Porras, 2002). We recognize these successes. However, we also believe the simple economic model, which so compellingly motivates MBC efforts, can fail in practice. Holling and Meffe (1996) argued that management of resources can set into motion dynamic forces that can reduce a system's resilience. Just as this holds for traditional management approaches, it is also true of $\mathrm{MBC}$, perhaps even more so. Using examples from diverse MBC applications, we argue that successful MBC initiatives must adapt to three constantly moving forces markets, social systems, and ecosystems.

\section{Defining market-based conservation}

Among the wide variety of MBC approaches, some clearly involve markets, whereas others have only one or two market-like features. Our list of MBC approaches is largely consistent with Pirard (2012: 62), including a wide range of conservation schemes unified only in that "a price is attributed to nature to different degrees and in different ways". The term MBC is applied to cases where a private landowner has nearly complete flexibility regarding the use of his or her land and to situations in which the agent's rights are limited. The term $\mathrm{MBC}$ can also apply when firms manage resources or it can apply in situations where those resources are managed by a community in which common ownership rights are respected.
We provide a simplistic model of the conservation problem and show how market-based incentives can correct that problem. This model shows the overarching concept of $\mathrm{MBC}$, but also reveals limits of a static MBC theory. Resource management can occur in a wide range of environments and can involve many decisions with multidimensional ecological outcomes that can be thought of as ranging from pure conservation at one extreme to complete conversion on the other extreme. To present a simplified version of the theory behind $\mathrm{MBC}$, we consider a simple problem of land management in which there are two options: conservation for nature or conversion to other uses.

Figure 1 presents a $2 \times 2$ matrix to illustrate four categories of benefits or costs associated with use of natural resources, depending upon whether they are private or public, and whether they are market or non-market. Private benefits are those the landowner takes into account when choosing between conservation and conversion. Benefits that accrue to those who do not own or control the land are called public. The distinction between market and nonmarket benefits refers to whether the benefits of an activity are actually reflected in monetary (or barter) transactions. For example, if birdwatchers enter freely into a forested area to view the wildlife, they are receiving a non-market benefit, but if they pay an entrance fee then this results in a market benefit. Market benefits can also be public, such as when a fruit tree farmer's yields increase because of the pollination provided by birds and insects that nest in a neighbour's forest.

For the manager(s) of a piece of land, the benefit of a management programme is the sum of the private market and private non-market benefits. However, there is also an opportunity cost to conservation - the manager gives up the benefits that $\mathrm{s} /$ he might gain from conversion. If this opportunity cost is greater than the benefits of conservation, then the conversion of the land will be in the manager's best interest. While certainly fallible, markets tend to succeed in allocating typical private goods and services; they provide incentives for firms to produce goods that people want and they do so at the lowest possible cost. However, when we are talking about conservation, market success is the exception rather than the norm. The reason is that many of the benefits of conservation are public, not private, on the right side of Figure 1.

Underprovision occurs when conversion accrues more benefit than conservation. This problem can, in theory, be corrected by MBC. The first bar in Figure 2 represents the benefits of conservation. Benefits below the thick solid line are private and accrue to the landowner. Public benefits are the amount above the thick line. The second bar presents the benefits of conversion, all of which we assume are private. ${ }^{1}$ There are also public benefits associated with conversion,

\footnotetext{
Frequently there are public benefits associated with conversion as well. These are ignored here to focus on the conservation problem. 


\begin{tabular}{|c|c|c|}
\hline & Private benefit or cost & Public benefit or cost \\
\hline $\begin{array}{l}\text { Non-market } \\
\text { Consequences }\end{array}$ & $\begin{array}{l}\text { A } \\
\text { Benefit: personal use of biodiversity } \\
\text { wildlife (e.g., wildlife viewing, hunting, } \\
\text { or fishing) } \\
\text { Cost: unrealized gain from other land } \\
\text { use options (e.g., amenities created by } \\
\text { conversion enjoyed by the owner) }\end{array}$ & $\begin{array}{l}\text { C } \\
\text { Benefit: existence value to people who } \\
\text { desire a species' conservation } \\
\text { Cost: unrealized public benefits of } \\
\text { land conversion (e.g., public amenities } \\
\text { created by conversion) }\end{array}$ \\
\hline $\begin{array}{l}\text { Market } \\
\text { Consequences }\end{array}$ & $\begin{array}{l}\text { B } \\
\text { Benefit: sale of rights to access } \\
\text { biodiversity (e.g., for wildlife viewing, } \\
\text { hunting, or fishing). } \\
\text { Cost: unrealized gain from conversion to } \\
\text { other land use options (e.g., commercial } \\
\text { real estate) }\end{array}$ & $\begin{array}{r}\text { D } \\
\text { Benefit: increased revenue to } \\
\text { neighbouring landowners due to } \\
\text { enhanced ecosystem services (e.g., } \\
\text { pollination) } \\
\text { Cost: unrealized public benefit of } \\
\text { conversion (e.g., amenities created by } \\
\text { the alternative land use) }\end{array}$ \\
\hline
\end{tabular}

Figure 1. Breakdown of different types of benefits and costs of conservation.

Source: Author's elaboration.

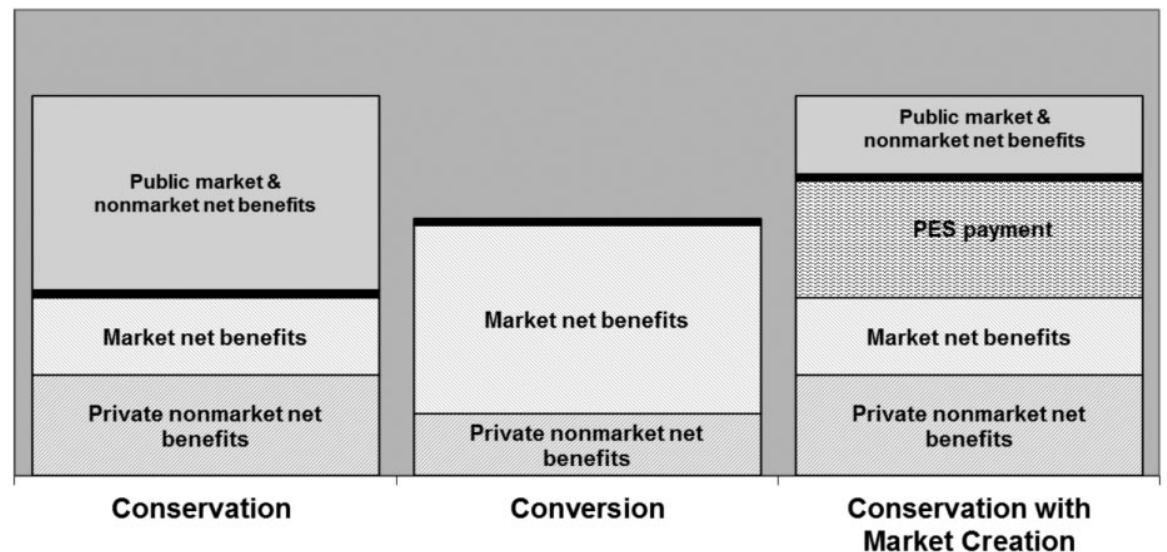

Figure 2. Stylized model of the private and public payoffs from conservation, conversion, and conservation with a PES programme in place. Source: Author's elaboration.

but we ignore them here to focus on the conservation problem. Although conservation yields more total benefits than conversion, conversion is more attractive in this simple model. As long as the land manager is not compensated for the public benefits, theory suggests that one will tend to choose conversion, which is not the best choice for society as a whole.

Any conservation policy, not just MBC, can be thought of as an attempt to change the incentives for the landowner so that conservation becomes more attractive. In principle, charitable contributions or voluntary coordination can also lead to conservation, and in some circumstances this has been highly effective (Ostrom, 1990). However, coordination takes time and effort, which makes reaching conservation agreements difficult to achieve. Coordination is an example of what economists call transaction costs (Coase, 1960), which are the costs in time or money required to (1) search for trading partners and obtain information, (2) bargain and make a decision, and (3) monitor and enforce the terms of a transaction. Although many stakeholders may benefit from conservation and the benefits may exceed the costs, transaction costs can inhibit deals that would lead to conservation.

Market-based conservation initiatives seek to increase the private market benefits of conservation. The third bar of Figure 2 represents one type of $\mathrm{MBC}$ policy, a programme in which the land manager who chooses to conserve is given a PES payment, perhaps for soil management practices that 
reduce erosion and stream sedimentation. The payment creates an additional private benefit of conservation, raising the thick line so that conservation now generates more private benefits for the manager than conversion. Note that we have assumed here that the PES payment reduces the public net benefits because those users now have to pay for the benefits they would receive freely under conservation without the PES programme.

\section{Types of market-based conservation}

A wide range of approaches have been described as market-based (Table 1). Like the PES example in Figure 2, all of these approaches attempt to make conservation more attractive by increasing the private benefits of conservation. We enumerate the wide array of policies and situations, ranging from direct methods like PES programmes that pay for specific services, to indirect methods like certification programmes (Ferraro and Kiss, 2002). The classification, or taxonomy, of MBC approaches (Table 1) is directly applicable to programmes in which conservation occurs through private decisions of individuals and firms. Cases may also apply to communities or indigenous groups, often with additional complexities. Pirard (2012) provides useful definitions of distinctions among the MBC approaches depending on how each approach relates to markets. Our focus is on the broad spectrum of policy MBC approaches and our taxonomy reflects the different types of policy interventions required in each case. In this regard, we suggest $\mathrm{MBC}$ schemes can be broken down into three groups that we call self-propagating conservation (SPC), state-created value (SCV), and conservation by market creation (CMC). A MBC scheme in any of these groups might succeed or fail depending on its specific design

Table 1. Examples and descriptions of "market-based" approaches to conservation"

\begin{tabular}{|c|c|c|c|}
\hline Approach & Description & Examples & Type $^{\text {b }}$ \\
\hline Direct Payments for Use & $\begin{array}{l}\text { Individuals or organizations pay land owners for } \\
\text { direct, conservation-oriented use of land }\end{array}$ & Hunting leases & SPC \\
\hline Private Land Acquisition & $\begin{array}{l}\text { Individual or organization purchases land out right } \\
\text { to conserve or restore }\end{array}$ & $\begin{array}{l}\text { Nature Conservancy purchase of land and } \\
\text { easements }\end{array}$ & SPC \\
\hline Bioprospecting & $\begin{array}{l}\text { Company pays owners of biodiversity rich land to } \\
\text { conduct research on potentially marketable } \\
\text { products and will often pay a percentage of } \\
\text { resulting profits }\end{array}$ & Shaman Pharmaceuticals & SPC \\
\hline Ecotourism & $\begin{array}{l}\text { Individuals pay third parties or owners directly for } \\
\text { relatively non-destructive access to areas of high } \\
\text { scenic or conservation interest }\end{array}$ & Sea turtle nesting tourism & $\mathrm{SPC} ; \mathrm{CMC}$ \\
\hline Conservation Easements & $\begin{array}{l}\text { Private land owners sell to non-profit organizations } \\
\text { or a government agency their right to develop } \\
\text { their land for set period. }\end{array}$ & Land trusts in the United States & $\mathrm{SPC} ; \mathrm{CMC}$ \\
\hline $\begin{array}{l}\text { Non-Timber Forest } \\
\text { Products }\end{array}$ & $\begin{array}{l}\text { The development of markets for non-timber forest } \\
\text { products (NTFPs), such as medicinal plants, } \\
\text { wild food products, rattan, etc., are encouraged } \\
\text { to create incentives for local resource managers } \\
\text { to favour extraction of NTFPs over more } \\
\text { destructive timber extraction. }\end{array}$ & Morocco's argan trees & $\mathrm{CMC}$ \\
\hline Certification & $\begin{array}{l}\text { Third party private or non-profit certification of } \\
\text { "eco-friendliness" of goods provides price } \\
\text { premium for grower }\end{array}$ & Shade-grown coffee certification & $\mathrm{CMC}$ \\
\hline Tradable Rights & $\begin{array}{l}\text { Governments place a cap on the number of } \\
\text { allowances, each of which gives a user the right } \\
\text { to use of the environment or natural resource. } \\
\text { Users can then trade allowances among } \\
\text { themselves. }\end{array}$ & $\begin{array}{l}\text { U.S. } \mathrm{SO}_{2} \text { allowance market Catch shares } \\
\text { programmes in fisheries }\end{array}$ & $\mathrm{SCV}$ \\
\hline $\begin{array}{l}\text { Payments for Ecosystem } \\
\text { Services }\end{array}$ & $\begin{array}{l}\text { Governments, corporations or groups of individuals } \\
\text { who directly benefit from specific ecosystem } \\
\text { services pay the owners of the land on which } \\
\text { they are produced (e.g. carbon offsets from } \\
\text { reforestation). Participants in a Cap and Trade } \\
\text { programme might pay for offsets, typically } \\
\text { treated as equivalent to allowances }\end{array}$ & $\begin{array}{l}\text { Costa Rica, Mexico \& China's national } \\
\text { PES programmes; New York City pays } \\
\text { farmers in Catskills for runoff abatement }\end{array}$ & $\mathrm{SPC} ; \mathrm{CMC} ; \mathrm{SCV}$ \\
\hline
\end{tabular}

Source: Author's elaboration.

Notes: ${ }^{a}$ Many MBC approaches are not exclusive to only one of our categories. ${ }^{\mathrm{b}}$ Types correspond to sections in the text: self-propagating conservation (SPC), conservation by market creation (CMC) and conservation by state-created value (SCV). 
and implementation and perhaps more importantly, on how policymakers anticipate the dynamic nature of social-ecological systems in which the MBC scheme is placed.

\subsection{Self-propagating conservation (SPC)}

When conservation is in the landowner's best interest due to existing markets and non-market incentives, it is self-propagating. In this case there is no need for direct governmental or non-governmental interventions. Examples include markets for hunting (Lindsey et al. 2006), private purchases of land or easements for conservation (Rissman et al., 2007), many examples of ecotourism (Brightsmith et al., 2008), and firms involved in bioprospecting, which seek to capitalize on the potential for pharmaceutical products in the rain forest (Clapp and Crook, 2002) which are referenced in Table 1. In these examples, various activities, such as ranching and farming that are not directed towards biodiversity conservation may nonetheless be consistent with conservation. While there may be some intervention by the state through regulations, permitting or promotion, SPC occurs with little to no effort by the government or environmental organizations.

\subsection{Conservation by state-created value (SCV)}

When private incentives for conservation do not already exist, the government can use a variety of approaches to make conservation more attractive. The clearest example of this is seen through subsidies given to landowners who adopt conservation practices as in the US Environmental Quality Incentives programme (Khanna, 2001). A less obvious example of $\mathrm{SCV}$ is found in tradable rights approaches such as the $\mathrm{SO}_{2}$ trading programme in the US (Evans and Woodward, 2013) or the individual transferable quotas that are used to manage fisheries in New Zealand (Newell et al., 2005). In a tradable rights system, commonly called cap-and-trade, firms are required to hold a right to make use of the environment, for example, by emitting pollutants or harvesting fish. Firms who use less than their allocation can sell rights, while firms that need more allowances are buyers in these markets. This qualifies as a case of SCV because the driver behind cap-and-trade programmes is a legal requirement that environmental harm by one party be offset through conservation elsewhere. An example of this in terms of conservation is the no-net-loss of wetlands programme in the US, which requires that wetland destruction in one place be offset through mitigation practices elsewhere (Robertson 2006). This law establishes incentives for the creation and protection of wetlands: those who create a wetland can sell credits, while those whose activities result in wetland loss are required to buy credits. Approaches in the category of SCV, therefore, include policies in which the price on the environment is placed directly and those where the price arises indirectly via a tradable rights market.

\subsection{Conservation by market creation (CMC)}

The final main type of MBC is what we call conservation by market creation (CMC). In this case, the benefits of conservation are not increased directly by the government as in $\mathrm{SCV}$, but are instead shifted indirectly by making it possible for the public to compensate land managers for the conservation services they create. This MBC concept is the basis for prototypical PES programmes (Wunder, 2005) in which beneficiaries of an environmental service pay the landowners who provide that service. In a pure PES programme, private beneficiaries voluntarily pay others to provide environmental improvements. For example, as part of Costa Rica's PES programme, owners of private hydroelectric plants have paid landowners to protect forest in the watersheds (Blackman and Woodward, 2010). However, these transactions did not arise organically as in SPC. Instead the market was created by a government entity that streamlines the process for making payments, sets the price for conservation, and monitors provision of the service.

Most actual PES programmes would best be characterized as examples of SCV, not CMC (Muradian et al., 2013). In China's sloping land initiative, most of the Costa Rica's programme, and Mexico's national PES programmes, it is the government, not individuals or firms that pays for conservation (Xu et al., 2004; Pagiola, 2008; McAfee \& Shapiro, 2010). Alternatively, some programmes described as PES are better thought of as SPC since they require little involvement of the government. This is true for the case of the Vittel Company in France, which paid dairy farmers upstream from their water bottling facility to reduce animal waste runoff (Perrot-Maitre, 2006).

Another type of $\mathrm{CMC}$ is certification, which provides a way for a beneficiary to pay a premium to producers who employ management that is more "environmentally friendly". There are numerous examples of certification programmes that promote conservation, often with criteria for social sustainability as well, including the Forest Stewardship Council's sustainable forestry certification (Auld et al., 2008; Ebeling \& Yasué, 2009) and Rainforest Alliance's certification programmes for shade grown, organic, and "bird-friendly" coffee (Perfecto et al., 2005; Philpott et al., 2007). The efforts of these organizations effectively created new differentiated products so that producers who sell these products can charge slightly higher prices than those who sell in the rest of the global market. These examples demonstrate how differentiated products can be created by entities other than governments, though governments too can play this role (e.g. USDA labeling for organic food). Nonetheless, intervention and monitoring by a third party is usually required to ensure that conservation is being achieved. When this is done, the public values of 
conservation can be transmitted through the market place to landowners who provide environmental benefits, making conservation more attractive.

Finally, CMC-type conservation can occur when buyers and sellers are connected via a tradable rights programme. For example, carbon offsets that are created under the Kyoto Protocol's Clean Development Mechanism are primarily used for compliance with an emission standard is an example of SCV. However, these offsets can also be sold directly to consumers who voluntarily seek to offset their own emissions (Gössling et al., 2007). Further, when the carbon offsets are generated through a project such as reforestation, the benefits valued by the buyer may include both biodiversity conservation and carbon emissions.

\section{Market-based conservation and dynamic systems}

The simple framework for MBC presented in Figure 2 and its policy implications are intuitively clear - if a policy can increase a private owner's net benefits, then conservation will be more attractive. The model is lacking, however, because of its inherent reductionist bias; it implicitly assumes that all else is held constant. The theory is static. But in practice, dynamic forces create new and complex challenges.

In the theories of both ecology and economics, selfregulating systems are common. In both predator-prey systems and simple supply and demand models a shock to the system leads to feedbacks that usually return the system back toward a stable equilibrium. As we show below, stabilizing feedbacks are often lacking in MBC. Ecologists and economists have long realized that traditional static models fail to reflect reality (see Holling, 1973), yet discussions of $\mathrm{MBC}$ have generally failed to keep up with such non-equilibrium thinking.

The systems with which MBC approaches interact markets, ecosystems, and social systems - are all in constant flux (Gunderson \& Holling, 2001). Moreover, we will show that through intended and unintended effects on these systems, MBC initiatives can actually accelerate unpredictable system dynamics that can substantially diminish the initiatives' long-term effectiveness. Of course, $\mathrm{MBC}$ conservation is not alone in facing these challenges; whether conservation is achieved through the incentives of markets or the fences of protected areas, these dynamic forces create long-term challenges. We focus on MBC approaches to emphasize areas where MBC faces challenges that we believe have been underappreciated, creating opportunities for future research and improvements in the implementation of MBC.

\subsection{Markets are dynamic}

Fluctuating markets, hidden costs, and the incentives created for unsustainable resource use are all examples of market forces that can undermine the conservation goals of a MBC scheme. Any one of these factors can shift the balance from conservation to conversion. And because conversion is often irreversible, even short-term fluctuations can lead to long term or permanent loss of the opportunity to conserve a resource.

\subsection{Market fluctuations produce inconstant incentives to conserve}

Predicting costs and potential returns can be particularly difficult in $\mathrm{MBC}$ approaches that require market creation $(\mathrm{CMC})$. The experience with shade grown coffee is representative. While generally providing lower yields than coffee grown without shade, plantations with shade have been shown to provide significant habitat for biodiversity (Perfecto et al., 1996). Beginning in the 1990s, a number of certification programmes were initiated that provided a price premium for farmers who maintained the more ecofriendly shade coffee. These certification programmes have included Bird-Friendly ${ }^{\mathrm{TM}}$ from the Smithsonian Institute and Rainforest Alliance, the UTZ Good Inside certification and Starbuck's C.A.F.E. Practices programme (Perfecto et al., 2007). The challenge in such markets is that prices may not adequately capture scarcity of the commodity conservation benefit. For example, if global coffee prices go down, coffee farmers will tend to switch to more profitable crops, resulting in a reduction in the environmental benefits provided by shade-grown coffee. While the price for the commodity should respond efficiently to changes in the relative demand and supply, it is more difficult for changes in the scarcity of the environmental service to be transmitted to the market because of the public nature of the benefits of conservation. The price premium for shadegrown coffee may not adjust sufficiently to incentivize producers to switch to eco-friendly practices. This is what occurred during the 1990s, when coffee prices fell to the point where, despite the premium paid for shade-grown coffee, farmers were forced to convert to alternative land uses (Calo and Wise, 2005). Evaluation of land use change data has shown a correlation between the international market crash and the clearing of shade-grown coffee plantations in Latin America to make way for pasture or cropland (Perfecto et al., 2007). Furthermore, as in any market, supply will tend to increase when the premium paid is high; so the price premium to certified crops can fall over time as the number of certified farms grows and certification itself becomes commoditized (International Trade Centre, 2011).

Other types of MBC initiatives are also subject to the vagaries of markets. Tourism is a major category among MBC approaches (Stronza, 2001) with cases classifiable as either SPC or CMC (Table 1). However, in some cases tourism is subject to boom-bust cycles. These are exacerbated by social or ecological disruptions, such as infectious disease, violence, and natural disasters. Even 
relatively minor political instability in a region can have significant impacts on tourism demand. When violence erupted in Kenya following the 2007 presidential elections, the New York Times reported that, "Scenes of migrating wildebeests and elephants in the Masaai Mara have been replaced with news photographs of rioting in Nairobi, churches burned to the ground and citizens fleeing the country" (Higgins, 2008). Within weeks, tourism dropped over $90 \%$ as travelers cancelled their arrangements (Gettleman, 2008). Collapses like this affect not only the people who work in the industry, but also the conservation programmes that depend on revenues from tourists as their driving incentive.

\subsection{Increases in market demand lead to unsustainable use}

Extraction of non-timber forest products (NTFPs) like nuts and rubber was one of the first $\mathrm{MBC}$ approaches, promoted as a way to operationalize the concept of "sustainable development" (Myers, 1988), typically with outside support $(\mathrm{CMC})$. The idea was that if local inhabitants participate in NTFP extraction, it would reduce damage to forest ecosystems and land managers could benefit from conservation and the commercialization of the NTFP harvests (Kusters et al., 2006). Ironically, due not to economic failure, but to economic success, this logic has not always held true over time.

Several reviews of NTFP initiatives have concluded that increasing commercialization of NTFPs often leads to environmental degradation, not protection. In a review of 61 cases of commercially viable NTFP initiatives, Kusters etal. (2006) found that in cases where species were commercially harvested from the wild with no other management, there was a tendency toward depletion of the target species. They also found a positive correlation between higher rates of degradation and the degree to which households were benefiting monetarily from NTFP sales of the environmental functions of harvested forests. The case of Morocco's argan trees, which produce the world's most expensive edible oil, is representative (Lybbert et al., 2011). Although the oil is regularly marketed as promoting poverty alleviation and biodiversity preservation, it has been much more successful in the former than the latter; the commercialization of this product has actually resulted in forest degradation. Lybbert et al. (2011: 13966) attribute this failure to achieve conservation goals to a "mismatch" of incentives; locals are "motivated more by immediate concerns about the fruit harvest than by any longer-term concern for tree or forest productivity".

As shown by Ruíz-Pérez et al. (2004), the argan forest example is not unique. Increasing market demand tends to lead to overexploitation of wild-harvested NTFPs. They find that greater levels of commercialization were correlated with a shift towards cultivation of the products in low diversity plantations or managed forest stands, moving away from use of naturally regenerated products. Although it appears that cultivation resulted in less degradation of the NTFP resources, this also effectively eliminates the incentive for ecosystem conservation.

Even non-extractive MBC can become unsustainable if an ecosystem is overwhelmed by unregulated market demand. An example would be ecotourism initiatives that degrade with excess or poorly managed visitation, cutting trails, or disturbing the wildlife (Ananthaswamy, 2004). The bottom line is that although NTFP initiatives increase the value of conservation, over time they can result in overexploitation or lead to the development of alternative supplies that undercut the prices charged for the products from native habitats.

\subsection{Hidden costs and unpredictable returns}

Other factors that can reduce the resilience of MBC are the costs of designing, administering, and carrying out conservation programmes. Whether government-run or community-based, MBC projects are often pursued because they are cheaper than more traditional parks and protected areas (Büscher, 2012). Hence, it should come as no surprise that governments often fail to take into account the costs associated with management and long-term population monitoring (Fitzgerald, 1994; Noss et al., 2005). In South America, tegu lizards (Tupinambis spp.) have remained among the most exploited reptiles in the world (Mieres and Fitzgerald, 2006). In one community-based programme in Bolivia, hunters established a fee in 2008 to support management programmes, but the funds generated have been insufficient to support indigenous parabiologists' salaries and the expenses of population monitoring (Cuéllar et al., 2010). Without subsidies to cover monitoring costs, the community-based system would be left without local expertise to monitor the wildlife resources and the harvest. Hence, despite its MBC structure, the programme still depends on conservation funds from NGOs to ensure that conservation objectives are met.

Initiatives that require market creation (CMC) carry start-up and maintenance costs, often borne by NGOs or government entities that may never be recouped. Iguana farms in Nicaragua fit this scenario. Started with grants to communities or individuals from international aid organizations or NGOs (Eilers et al., 2002), the maintenance costs for the farms are relatively high and profit margins are small. Without additional financial inputs, it is unlikely that iguana farms will expand to other communities. Hence, though the iguana farms might be seen as an approach that could prove self-propagating, the barriers to expanding on the model are significant.

A general pattern emerges from these cases: markets typically value the products sold, not the ecosystems that sustain those products. Hence, the market feedbacks that lead to supply responding to scarcity will often be lacking for the ancillary environmental benefits associated with a 
production process. Further, similar signals of scarcity are not automatically transmitted to the policymakers who are critical to the scheme's success when third-party involvement is required (CMC or SCV). Unless ecosystem conservation is required for production, either naturally or through regulation, the economic incentives for conservation will be insufficient and, in the long run, the MBC initiatives alone may not achieve the conservation goals. Taken together, these cases show how difficult it is for $\mathrm{CMC}$ to shift the line away from land conversion towards conservation. Policymakers must continually assess whether the incentives for conservation are still in place. Designers of $\mathrm{MBC}$ initiatives must intentionally respond to changes in the market; it will not happen automatically. If not, they may find that their conservation goals have been subverted by the very market forces they had hoped to harness.

\section{Social systems are dynamic}

Incentives in $\mathrm{MBC}$ approaches can also shift for primarily social reasons. Humans respond to a wide range of incentives: moral, spiritual, aesthetic, cultural, social, and economic. While the framework of Figure 2 presents nonmarket and market benefits as additive, behavioural economists have noted that economically incentivized individuals actually live in a world of "incomplete contracts" in which the consequences of bad or good behaviour are vaguely encompassed in social norms and relations (Gneezy and Rustichini, 2000; Bowles and Polanía-Reyes, 2012). Economic incentives can give clarity to the consequences, creating a positive incentive to conserve. However, this can alter the perceived importance of societal pressures that dissuade environmentally harmful behaviour. Further, a MBC construct almost inevitably focuses on part of the ecosystem's goods or services at the expense of others. This commoditization is reductionist and it is "obscuring ecosystems' complexity and establishing boundaries within ecosystems which are difficult, if not impossible to draw" (Kosoy and Corbera, 2010: 1,231). Finally, MBC can promote social forces that previously encouraged at least some level of conservation. In this section we will give examples of how MBC approaches can disrupt social incentives for conservation.

\subsection{Disruption of social norms}

When markets are introduced in rural, subsistence communities, they lead to new incentives, values, and relations (Godoy et al., 2005; Lu, 2007). This is true whether the market is for potatoes or ecosystem services. The financial returns from $\mathrm{MBC}$ initiatives are often distributed unequally, which can intensify social stratification and disrupt social norms of fairness, equality, and reciprocity (Godoy et al., 2004). Such changes can fuel rather than abate environmental degradation.
In 1999, an ecotourism company established an MBC project (CMC) to protect Harpy eagles (Harpia harpyja) and their nests in an indigenous community of the Peruvian Amazon. As part of an overall effort to manage the ecosystem, local Ese Eja and mestizo farmers were paid to find and guard Harpy nests (Stronza, 2010). Any individual who found an active nest was entitled to become a "guardian", protecting the nest from potential hunters. In exchange, the farmers earned one dollar per tourist viewing. Historically, although Harpy eagles had cultural importance to the Ese Eja, one observer said that the people thought of the bird as "just another chicken" (Peluso and Alexiades, 2005). With the advent of the tourism, the eagles retained symbolic significance into the late 1990 s, were hunted only on rare occasions and treated more like a community mascot. In the second year of the guardian programme, however, a Harpy was reportedly shot and killed. Many in the community blamed the guardian programme itself because it sparked rivalries among people; someone killed the eagle not to collect feathers, but to spite its guardian (Stronza, pers. obs.). While this is only an isolated case, it demonstrates how MBC can result in not only increased benefits from a resource, but also the concentration of those benefits into the hands of a few. As anticipated by Muradian et al. (2013), a payment for conservation had the perverse effect of disrupting the social norms that had previously helped protect the resource in question.

\subsection{Spatial and temporal displacement of degrading activities}

When an MBC effort leads to increased income, it can sometimes result in what economists have called a "wealth effect". As local people gain income, they may invest their earnings in land conversion (Zwane, 2007; Alix-Garcia et al., 2010). Stronza (2007) found that new income from community-based ecotourism (SPC) had countervailing effects on conservation. Employment through tourism was associated with declines in direct resource use such as hunting and forest clearing, but new income also enabled other forms of consumption. Some community members used their earnings to hire labourers to clear more forest. Stronza (2010) also found that ecotourism led to a relatively new and dualistic way of thinking about nature and people. Though the community-based reserve is relatively well-protected, areas outside of the reserve are increasingly perceived as open for maximum use and development. One man who had cleared a large tract of forest for his field explained, "We have our reserve. But outside of the reserve, we can clear all of our forest" (Stronza, 2010: 72).

If people accept a conservation programme based on economic benefits, it is also reasonable to assume that they will reject it if a better economic alternative comes along. Further, the amount that the stewards of environmental 
goods and services require for their sacrifices will tend to change as their quality of life and income expectations rise and fall. It may reach the point where people perceive conservation practices as too restrictive, regardless of the amount of benefits delivered.

\subsection{Market-based initiatives can exacerbate income inequalities}

$\mathrm{MBC}$ initiatives are often promoted as win-win policies, delivering both conservation and poverty alleviation (Morales and Penny, 2009). Some argue that the poor will benefit from MBC since they are in a position to gain from selling environmental goods or services (Scherr et al., 2003). However, the poorest of the poor are unlikely to have access to the opportunities, information, and skills necessary to profit from MBC initiatives. As such, for MBC to both conserve and benefit the poor, significant obstacles need to be overcome (Lybbert et al. 2004; Pagiola et al., 2005).

Some scholars argue that privatizing and creating a commodity of a previously free good or service of nature can only hurt the poor. This is because increases in the monetary value of a resource often lead to its expropriation by more economically or politically powerful actors (Lovera, 2004). For example, financial incentives have arisen for Reduced Emissions from Deforestation and Degradation (REDD) as a way to mitigate climate change. While often cited for its ability to alleviate poverty (Morales \& Penny, 2009), because of political corruption and lack of clear rule of law in developing countries, REDD programmes can instead provide a way to prey on the poorest and most vulnerable. In Papua New Guinea, the office of Climate Change and Environmental Sustainability is reported to have sold approximately US\$ 85 million of carbon credits to an Australian company without consulting the forest communities who are the legal owners of the land (Rights and Resources Initiative, RRI, 2010). Elsewhere, "carbon entrepreneurs" have been accused of convincing poor landowners to sign over rights to their forest carbon for low prices; selling "shares" in fictitious carbon trading companies, or, in at least one instance, kidnapping a community leader at gunpoint until he agreed to sign over forest carbon rights (Gridneff, 2009; RRI, 2010).

In many cases, the ability of the poor to "sell" environmental resources or services is limited by lack of capital or secure property rights (Pagiola et al., 2005). It is often the wealthier, the more educated, and the politically savvy who reap the benefits of MBC. Kosoy et al. (2007) studied a PES programme operated by the city of Heredia, Costa Rica, and found the landowners receiving payments had an average annual income of US\$ 60,000 (over ten times the 2006 national average). Numerous studies showed how eco-certification imposed significant monetary, labour, and organizational costs on small producers of organic agricultural products (Mutersbaugh, 2002; González and
Nigh, 2005), forest products (Taylor, 2005), and non-timber forest products. Small landholders, therefore, faced the disadvantage of higher relative costs of participating in these initiatives (Thornber et al., 1999).

If $\mathrm{MBC}$ approaches are effective and efficient means of promoting conservation, should the effect on the poor be considered? Some in the conservation community have called for conservation regardless of social impacts (Terborgh et al., 2002). We agree with those who point out that even if conservation is the main concern, it is critical to pay attention to impacts on the poor (Barrett, 1996; Berkes and Folke, 1998). This will often require specific strategies to help poor participants: providing them with start-up capital, guaranteeing prices, and making payments at regular intervals so as to minimize risk (Taylor, 2005). On the other hand, there is evidence that a more traditional approach of establishing a protected area can be effective at reducing poverty (Ferraro et al., 2011) - so MBC is not the only way to achieve conservation while helping the poor.

\section{Ecosystems are dynamic}

Ecologists have understood for decades that ecological systems are not in equilibrium (Holling, 1973). Environmental disturbance and spatial heterogeneity are each correlated with high levels of biodiversity and these are both unpredictable and dynamic (Huston, 1994). The realization that ecological changes are to be expected forms the basis for modern adaptive management approaches to natural resource problems (Walters, 1986).

Natural stochastic fluctuations in plant and animal populations bring uncertainty into all conservation schemes. Yet the simplistic theoretical foundation for MBC that we described above presumes a predictable environment, non-changing landscapes, and stable ecosystem conditions. Any number of factors, either anthropogenic or "natural", can cause changes in plant and animal distributions and abundances that can undermine a MBC strategy.

A clear example of this occurs in the resort town of Playa Grande, Costa Rica. The town enjoyed tourism revenue from leatherback turtle viewing, supporting a number of conservation initiatives (SPC). However, due to factors beyond Playa Grande and the nearby Las Baulas National Marine Park, there was a precipitous decline in the numbers of leatherback turtles nesting on the beach. With the turtles' decline, the beaches are no longer drawing tourists for turtle viewing, diminishing the ability of conservationists to win political and economic battles to protect the beaches for the turtles (Rosenthal, 2009). The turtle museum closed and visitation to the park declined drastically. Recently, biologists sought a 140-yard buffer for development to protect the turtle's nesting grounds, but this would have required expensive buyouts of beachfront property. The government set a much smaller buffer, a compromise that 
scientists fear will result in "certain extinction" (Rosenthal, 2009).

A second example of how environmental fluctuations can frustrate the goals of MBC schemes is seen in coral reef bleaching, which results from natural and anthropogenic causes. The massive 1997-98 bleaching event related to abnormally high sea surface temperatures affected reefs all over the world (Goreau etal., 2000). Scholars have examined the effects of coral reef bleaching on divetourism, fisheries, and other reef-related $\mathrm{MBC}$ activities (e.g. Schuttenberg, 2001, and papers cited therein). The impact of the 1997-98 massive bleaching on short-term reef-related tourism revenues amounted to millions of US\$ each in Zanzibar, Kenya, the Maldives, and the Philippines (Schuttenberg, 2001). Falling tourism revenues can diminish incentives for conservation in these areas.

Dynamic ecosystems can lead to problems in transferable rights programmes as well. In the US $\mathrm{SO}_{2}$ trading programme (SCV), for example, scientific evidence in the 1990s began to show how the cap on emissions was set too high and regional differences in emissions were more important and complex than originally understood. The US Environmental Protection Agency (EPA) was forced to make adjustments to the programme to attempt to correct these problems. In the end, however, these adjustments led to legal problems for the programme that resulted in its eventual downfall (Evans and Woodward, 2013).

Fortunately, not all MBC approaches are subject to these perverse feedbacks. An example of reinforcing feedbacks can be seen in transferable catch shares programmes in fisheries (SCV) (Costello et al., 2008). In such programmes, the total harvest varies with estimates of the species' population so if the stock declines, the allowable take is reduced, making the rights more valuable. This creates an incentive among fishers who hold rights to monitor for illegal harvests when protection is most needed.

\section{Conclusions}

Over the last two decades, MBC initiatives have been increasingly sought as the way to protect the environment and our natural resources. There are many types of policies that are referred to as market-based, but they share the common goal of shifting the incentives in favour of conservation. One important dimension along which MBC approaches differ is in the role played by policymakers in the programme. We divide MBC approaches into three main classes: self-propagating conservation, state-created value, and conservation by market creation. Understanding this distinction will help readers understand the commonalities among MBC schemes while also seeing the different roles that are played by policymakers.

While there are many examples of cases when MBC has contributed to conservation efforts, painful experiences reveal that the simple logic of $\mathrm{MBC}$ fails to account for the dynamic world in which the programmes are set. $\mathrm{MBC}$ schemes can only be successful if they adapt to the complex dynamics of ecosystems, social systems, and the market. But because most often the benefits of conservation are public, not private, the value of conservation is rarely captured directly in any markets themselves. Hence, selfregulating feedback mechanisms are usually weak or absent. Rather, policymakers need to understand these dynamics and they may need to intervene to ensure that conservation outcomes are achieved. Since the dynamic forces involve the complex interactions of economic, social and biological factors, multidisciplinary analysis that goes well beyond the simple theoretical model of Figure 2 is needed. This can be logistically difficult and costly; but there are examples where such work is being done successfully (Robertson, 2006; Perfecto et al., 2005; Steffan-Dewenter et al., 2007).

Market-based conservation is not a panacea and it is often not even a suitable substitute for strong state intervention. Most MBC schemes are cases of either CMC or SCV in which a deliberate intervention by a government or NGO is needed. Any approach can result in unanticipated dynamic responses that frustrate conservation goals (Holling \& Meffe, 1996) and MBC is no exception. Such schemes are most likely to succeed when they are buttressed by other forms of protection, supported by good science, and designed to be robust to the changing conditions in which ecosystems exits. A balanced approach, using MBC but not relying on it alone, is most likely to yield sustainable conservation outcomes.

\section{Acknowledgements}

We acknowledge support of the Texas A\&M Applied Biodiversity Science Program, NSF IGERT DGE 0653477 and Texas AgriLife Research. Woodward recognizes the support of the Cooperative State Research, Education \& Extension Service, Hatch Project TEX8604. Helpful comments were provided by students and faculty from the TAMU Applied Biodiversity Science Program, seminar participants at the University of Idaho, and Kendra Williamson. Michele Zinn provided editorial assistance.

\section{References}

Alix-Garcia, J.M., McIntosh, C., Sims, F., Welch, J., 2010. Development and Deforestation in Mexico: Impacts using the Discontinuity in Eligibility for Opportunities. University of Wisconsin Press, Madison, WI.

Ananthaswamy, A., 2004. Massive growth of ecotourism worries biologists. New Scientist. http://www.newscientist.com/ article.ns?id=dn4733 (accessed 1 December 2010).

Auld, G., Gulbrandsen, L.H., McDermott, C.L., 2008. Certification schemes and the impacts on forests and forestry. Annual Review of Environment and Resources, 33: 187-211.

Barrett, C.B., 1996. Fairness, stewardship and sustainable development. Ecological Economics, 19(1): 11-17.

C 2014 The Authors. Natural Resources Forum (C) 2014 United Nations 
Berkes, F., Folke, C., 1998. Linking Social and Ecological Systems: Management Practices and Social Mechanisms for Building Resilience. Cambridge University Press, Cambridge.

Blackman, A., Woodward, R.T., 2010. User-financing in a national payments for environmental services program: Costa Rican hydropower. Ecological Economics, 69(8): 1626-1638.

Bowles, S., Polanía-Reyes, S., 2012. Economic incentives and social preferences: Substitutes or complements? Journal of Economic Literature, 50(2): 368-425.

Büscher, B.E., 2008. Conservation, neoliberalism, and social science: A critical reflection on the SCB 2007 annual meeting in South Africa. Conservation Biology, 22(2): 229-231.

Büscher, B.E., 2012. The political economy of Africa's natural resources and the 'Great Financial Crisis'. Tijdschrift voor Economische en Sociale Geografie, 103(2): 136-149.

Brightsmith, D.J., Stronza, A., Holle, K., 2008. Ecotourism, conservation biology, and volunteer tourism: A mutually beneficial triumvirate. Biological Conservation, 141(11): 2832-2842.

Calo, M., Wise, T.A., 2005. Revaluing peasant coffee production: Organic and fair trade markets in Mexico. Global Development and Environment Institute, Tufts University, Medford, MA.

Chan, K.M., Pringle, R.M., Ranganathan, J., Boggs, C.L., Chan, Y.L., Ehrlich, P.R., Haff, P.K., Heller, N.E., Al-Khafaji, K., Macmynowski, D.P., 2007. When agendas collide: human welfare and biological conservation. Conservation Biology, 21(1): 59-68

Clapp, R.A., Crook, C., 2002. Drowning in the magic well: Shaman Pharmaceuticals and the elusive value of traditional knowledge. The Journal of Environment \& Development, 11(1): 79-102

Cleary, D., 2006. The questionable effectiveness of science spending by international conservation organizations in the tropics. Conservation Biology, 20(3): 733-738.

Coase, R.E., 1960. The problem of social cost. Journal of Law and Economics, 3(1): 1-44.

Costello, C., Gaines, S.D., Lynham, J., 2008. Can catch shares prevent fisheries collapse? Science, 321(5896): 1678-1681.

Cuéllar, R.L., Fitzgerald, L., Mendoza, F., 2010. Manejo comunitario de peni (Tupinambis rufescens) y taitetu (Tayassu tajacu). In: Gómez, H., Llobet, A. (Eds.), Isoso: Una Iniciativa de Conservación a Largo Plazo. Experiencias de Manejo de Fauna Silvestre en Bolivia. Editorial FAN, Santa Cruz de la Sierra. 58-82.

Ebeling, J., Yasue, M., 2009. The effectiveness of market-based conservation in the tropics: Forest certification in Ecuador and Bolivia. Journal of Environmental Management, 90(2): 1145-1153.

Eilers, K., Koops, W., Udo, H., Van Keulen, H., Noordhuizen, J., 2002. Analysis of iguana farming systems in Nicaragua, Costa Rica and Panama. Interciencia, 27(11): 599-606.

Engel, S., Pagiola, S., Wunder, S., 2008. Designing payments for environmental services in theory and practice: An overview of the issues. Ecological Economics, 65(4): 663-674.

Erhenfeld, D., 2008. Neoliberalization of conservation. Conservation Biology, 22(5): 1091-1092.

Evans, D.A., Woodward, R.T., 2013. What can we learn from the end of the grand policy experiment? The collapse of the national $\mathrm{SO} 2$ trading programme and implications for tradable permits as a policy instrument. Annual Review of Resource Economics, 5(1): 325348.

Ferraro, P.J., Kiss, A., 2002. Direct payments to conserve biodiversity. Science, 298(5599): 1718-1719.

Ferraro, P.J., Hanauer, M.M., Sims, K.R.E., 2011. Conditions associated with protected area success in conservation and poverty reduction. Proceedings of the National Academy of Sciences of the United States of America, 34(108): 13907-13912.

Fitzgerald, L.A., 1994. Tupinambis lizards and people: A sustainable use approach to conservation and development. Conservation Biology, 8(1): 12-15.

Gettleman, J., 2008. Kenya's tourism industry in shambles. The New York Times. Available from http://video.nytimes.com/video/2008/02/29/ world/africa/1194817122336/kenya-s-tourism-industry-in-shambles .html (accessed 1 May 2009).

Gneezy, U., Rustichini, A., 2000. A fine is a price. Journal of Legal Studies, 29(1): 1-17.

Godoy, R.A., Gurven, M., Byron, E., Reyes-Garcia, V., Keough, J., Vadez, V., Wilkie, D., Leonard, W.R., Apaza, L., Huanca, T., Perez, E., 2004. Do markets worsen economic inequalities? Kuznets in the bush. Human Ecology, 32(3): 339-364.

Godoy, R., Reyes-Garcia, V., Byron, E., Leonard, W.R., Vadez, V., 2005. The effect of market economies on the well-being of indigenous peoples and on their use of natural resources. Annual Review of Anthropology, 34: 122-138.

Gössling, S., Broderick, J., Upham, P., Ceron, J.-P., Dubois, G., Peeters, P., Strasdas, W., 2007. Voluntary carbon offsetting schemes for aviation: Efficiency, credibility and sustainable tourism. Journal of Sustainable tourism 15(3): 223-248.

González, A.A., Nigh, R., 2005. Smallholder participation and certification of organic farm products in Mexico. Journal of Rural Studies, 21(4): 449-460.

Goreau, T., McClanahan, T., Hayes, R., Strong, A., 2000. Conservation of coral reefs after the 1998 global bleaching event. Conservation Biology, 14(1): 5-15.

Gridneff, I., 2009. Carbon conmen selling the sky. The Sydney Morning Herald, June 13. Available from http://www.smh.com.au/world/ carbon-conmen-selling-the-sky-20090612-c63i.html (accessed 4 November 2014).

Gunderson, L., Holling, C.S. (Eds.) 2001. Panarchy: Understanding Transformation in Human and Natural Systems. Island Press, Washington, DC.

Higgins, M., 2008. Practical traveler: Kenya uncertainties in the shadow of unrest. The New York Times January 13. Available from http:/ travel.nytimes.com/2008/01/13/travel/13prackenya.html?scp=1 andsq $=$ kenya $\% 20$ safari $\% 20$ terrorism $\% 20$ violenceandst $=$ cse $\quad$ (accessed 1 May 2009).

Holling, C.S., 1973. Resilience and stability of ecological systems. Annual Review of Ecology and Systematics, 4: 1-23.

Holling, C.S., Meffe, G.K., 1996. Command and control and the pathology of natural resource management. Conservation Biology, 10(2): 328-337.

Huston, M.A., 1994. Biological diversity: The Coexistence of Species on Changing Landscapes. Cambridge University Press, Cambridge.

International Trade Centre, 2011. The impacts of private standards on producers in developing countries. International Trade Centre, Geneva.

Khanna, M., 2001. Non-mandatory approaches to environmental protection. Journal of Economic Surveys, 15(3): 291-324.

Kosoy, N., Corbera, E., 2010. Payments for ecosystem services as commodity fetishism. Ecological Economics, 69(6): 1228-1236.

Kosoy, N., Martinez-Tuna, M., Muradian, R., Martinez-Alie, L., 2007. Payments for environmental services in watersheds: Insights from a comparative study of three cases in Central America. Ecological Economics, 61(2-3): 446-455.

Kusters, K., Achdiawan, R., Belcher, B., Ruíz Pérez, M., 2006. Balancing development and conservation? An assessment of livelihood and environmental outcomes of nontimber forest product trade in Asia, Africa and Latin America. Ecology and Society, 11(2): 20.

Landell-Mills, N., Porras, I., 2002. Silver bullet or fools' gold? A global review of markets for forest environmental services and their impact on the poor. International Institute for Environment and Development, London.

Lindsey, P.A., Alexander, R., Frank, L.G., Mathieson, A., Romanach, S.S., 2006. Potential of trophy hunting to create incentives for wildlife conservation in Africa where alternative wildlife-based land uses may not be viable. Animal Conservation, 9(3): 283-291.

Lovera, S., 2004. Environmental markets impoverish the poor. Available from http://ecosystemmarketplace.com/pages/article.opinion.php ?component_id=2268andcomponent_version_id=3867andlanguage _id=12 (accessed 1 February 2009). 
Lu, F., 2007. Integration into the market among indigenous peoples: A cross-cultural perspective from the Ecuadorian Amazon. Current Anthropology, 48(4): 593-602.

Lybbert, T., Barrett, C.B., Narjisse, H., 2004. Does resource commercialization induce local conservation? A cautionary tale from southwestern Morocco. Society and Natural Resources, 17(5): 413-430.

Lybbert, T.J., Aboudrare, A., Chaloud, D., Magnan, N., Nash, M., 2011. Booming markets for Moroccan argan oil appear to benefit some rural households while threatening the endemic argan forest. PNAS 108(34): 13963-13968.

McAfee, K., Shapiro, E.N., 2010. Payment for ecosystem services in Mexico: Nature, neoliberalism, social movements and the state. Annals of the Association of American Geographers, 100(3): 579-599.

McCauley, D.J., 2006. Selling out on nature. Nature, 443(7): 27-28.

Mieres, M.M., Fitzgerald, L.A., 2006. Managing and monitoring the tegu trade in Paraguay. Journal of Wildlife Management, 70(6): 1723-1734.

Morales, A., Penny, T., 2009. US pledges \$1billion toward \$3.5 billion deforestation fund [Electronic Version]. Bloomberg News. Available from http://www.bloomberg.com/apps/news?pid=20601081 andsid $=$ aIp5RvRvc16A (accessed 1 December 2009).

Muradian, R., et al., 2013. Payments for ecosystem services and the fatal attraction of win-win solutions. Conservation Letters, 6(4): 274-279.

Mutersbaugh, T., 2002. The number is the beast: A political economy of organic-coffee certification and producer unionism. Environment and Planning A, 34(7): 1165-1184.

Myers, N., 1988. Tropical forests: much more than stocks of wood. Journal of Tropical Ecology, 4(4): 209-221.

Newell, R.G., Sanchirico, J.N., Kerr, S., 2005. Fishing quota markets. Journal of Environmental Economics and Management, 49(3): 437-462.

Noss, A.J., Oetting, I., Cuellar, R.L., 2005. Hunter self-monitoring by the Isoseño-Guaraní in the Bolivian Chaco. Biodiversity and Conservation, 14: 2679-2693.

Ostrom, E., 1990. Governing the commons: The evolution of institutions for collective action. Cambridge University Press, New York.

Pagiola, S., 2008. Payments for environmental services in Costa Rica. Ecological Economics, 65(4): 712-724.

Pagiola, S., Arcenas, A., Platais, G., 2005. Can payments for environmental services help reduce poverty? An exploration of the issues and the evidence to date from Latin America. World Development, 33(2): 237-253.

Palmer, M., et al., 2004. Ecology for a crowded planet. Science, 304(5675): 1251-1252.

Peluso, D.M., Alexiades, M.N., 2005. Urban ethnogenesis begins at home: The making of self and place amidst Amazonia's environmental economy traditional dwellings and settlements. Review, 16(2): 110.

Perfecto, I., Armbrecht, I., Philpott, S.M., Soto-Pinto, L., Dietsch, T.V., 2007. Shaded coffee and the stability of rainforest margins. In: Tscharntke, T., Leuschner, C., Zeller, M., Guhardja, E., Bidin, A. (Eds.), The Stability of Rainforest Margins, Linking Ecological, Economic and Social Constraints. Springer Verlag, Berlin. 227-263.

Perfecto, I., Rice, R.A., Greenberg, R., Van der Voort, M.E., 1996. Shade coffee: A Disappearing Refuge for Biodiversity. Bioscience, 46(8): 598-608.

Perfecto, I., Vandermeer, J., Mas, A., Pinto, L.S., 2005. Biodiversity, yield, and shade coffee certification. Ecological Economics, 54(4): 435-446.

Perrot-Maitre, D., 2006. The Vittel payments for ecosystem services: a "perfect" PES case? International Institute for Environment and Development, London.

Pirard, R., 2012. Market-based instruments for biodiversity and ecosystem services: A lexicon. Environmental Science \& Policy, 19-20: 59-68.

Philpott, S.M., Bichier, P., Rice, R., Greenberg, R., 2007. Field-testing ecological and economic benefits of coffee certification programmes. Conservation Biology, 21(4): 975-985.
Rights and Resources Initiative (RRI), 2010. The end of the hinterland: Forests, conflict and climate change. Washington D.C. Available from http://www.rightsandresources.org/documents/files/doc_1400.pdf (accessed 1 October 2011)

Rissman, A.R., Lozier, L., Comendant, T., Kareiva, P., Kiesecker, J.M., Shaw, M.R., Merenlender, A.M., 2007. Conservation easements: Biodiversity protection and private use. Conservation Biology, 21(3): 709-771

Robertson, M.M., 2006. Emerging ecosystem service markets: Trends in a decade of entrepreneurial wetland banking. Frontiers in Ecology and the Environment, 4(6): 297-302.

Robinson, J.G., Redford, K.H., (Eds.) 1991. Neotropical Wildlife Use and Conservation. Chicago University Press, Chicago, IL.

Rosenthal, E., 2009. Turtles are casualties of warming in Costa Rica. New York Times, November 13. A8

Roth, A.E., 2008. What have we learned from market design? The Economic Journal, 118(527): 285-310.

Ruíz Pérez, M., Belcher, B., Achdiawan, R., Alexiades, M., Aubertin, C., Caballero, J., Campbell, B., Clement, C., Cunningham, T., Fantini, A., de Foresta, H., Fernández, C.G., Gautam, K.H., Martínez, P.H., de Jong, W., Kusters, K., Kutty, M.G., López, C., Fu, M., Alfaro, M.A.M., Raghavan Nair, T.K., Ndoye, O., Ocampo, R., Rai, N., Ricker, M., Schreckenberg, K., Shackleton, S., Shanley, P., Sunderland, T., Youn, Y.-C., 2004. Markets drive the specialization strategies of forest peoples. Ecology and Society, 9(2): NIL_23.

Scherr, S., White, T.A., Kaimowitz, D., 2003. A new agenda for forest conservation and poverty reduction: Making markets work for low-income producers. Forest Trends, Washington, DC.

Schuttenberg, H.Z., 2001. Coral bleaching: Causes, consequences, and response: Selected Papers presented at the 9th International Coral Reef Symposium on "Coral bleaching: assessing and linking ecological and socioeconomic impacts, future trends and mitigation planning". Coastal Management Report \#2230. ISBN \#1-885454-40-6.

Spiteri, A., Nepal, S., 2006. Incentive-based conservation programmes in developing countries: A review of some key issues and suggestions for improvements. Environmental Management, 37(1): 1-14.

Steffan-Dewenter, I., Kessler, M., Barkmann, J., Bos, M.M., Buchori, D., Erasmi, S., Faust, H., Gerold, G., Glenk, K., Gradstein, S.R., Guhardja, E., Harteveld, M., Hertel, D., Hohn, P., Kappas, M., Kohler, S., Leuschner, C., Maertens, M., Marggraf, R., Migge-Kleian, S., Mogea, J., Pitopang, R., Schaefer, M., Schwarze, S., Sporn, S.G., Steingrebe, A., Tjitrosoedirdjo, S.S., Tjitrosoemito, S., Twele, A., Weber, R., Woltmann, L., Zeller, M., Tscharntke, T., 2007. Tradeoffs between income, biodiversity, and ecosystem functioning during tropical rainforest conversion and agroforestry intensification. Proceedings of the National Academy of Sciences of the United States of America, 104(12): 4973-4978.

Stronza, A., 2001. The anthropology of tourism: Forging new ground for ecotourism and other alternatives. Annual Review of Anthropology, 30 : 261-283.

Stronza, A., 2007. The Economic promise of ecotourism for conservation. Journal of Ecotourism, 6(3): 170-190.

Stronza, A., 2010. Commons management and ecotourism: Ethnographic evidence from the Amazon. International Journal of the Commons, 4(1): 56-77.

Sutherland, W.J., Adams, W.M., Aronson, R.B., Aveling, R., Blackburn, T.M., Broad, S., Ceballos, G., Cote, I.M., Cowling, R.M., Da Fonseca, G.A.B., Dinerstein, E., Ferraro, P.J., Fleishman, E., Gascon, C., Hunter Jr., M., Hutton, J., Kareiva, P., Kuria, A., Macdonald, D.W., Mackinnon, K., Madgwick, F.J., Mascia, M.B., McNeely, J., Milner-Gulland, E.J., Moon, S., Morley, C.G., Nelson, S., Osborn, D., Pai, M., Parsons, E.C.M., Peck, L.S., Possingham, H., Prior, S.V., Pullin, A.S., Rands, M.R.W., Ranganathan, J., Redford, K.H., Rodriguez, J.P., Seymour, F., Sobel, J., Sodhi, N.S., Stott, A., Vance-Borland, K., Watkinson, A.R., 2009. One Hundred questions of importance to the conservation of global biological diversity. Conservation Biology, 23(3): 557-567. 
Taylor, P.L., 2005. A fair trade approach to community forest certification? A framework for discussion. Journal of Rural Studies, 21(4): 433-447.

Terborgh, J., Van Schaik, C., Davenport, L., Rao, M., 2002. Making Parks Work: Strategies for Preserving Tropical Nature. Island Press, Washington, DC.

Thornber, K., Plouvier, D., Bass, S., 1999. Certification: Barriers to benefits. European Forest Institute, Discussion Paper 8, 1999. http:// northerntosia.org/files/attachments/dp_08.pdf (accessed 4 November 2014).

Walters, C.J., 1986. Adaptive Management of Renewable Resources. McMillan, New York.
Wunder, S., 2005. Payments for environmental services: Some nuts and bolts. CIFOR Occasional Paper No .42. CIFOR: Jakarta. http:// www.cifor.cgiar.org/publications/pdf_files/occpapers/op-42.pdf (accessed 4 November 2014).

Xu, Z., Bennett, M.T., Tao, R., Xu, J., 2004. China's sloping land conversion programme four years on: current situation and pending issues. International Forestry Review, 6(4): 317-326.

Zwane, A., 2007. Does poverty constrain deforestation? econometric evidence from Peru. Journal of Development Economics, 84(1): 330-349. 